\title{
Actinoplanes rishiriensis sp. nov., a novel motile actinomycete isolated by rehydration and centrifugation method
}

\author{
Hideki Yamamura $^{1}$, Aya Shimizu ${ }^{1}$, Youji Nakagawa ${ }^{1}$, Moriyuki Hamada ${ }^{2}$, Misa Otoguro ${ }^{2}$, Tomohiko Tamura ${ }^{2}$ \\ and Masayuki Hayakawa ${ }^{1}$
}

The motile actinomycete strain RI50-RCA1 $14^{\top}$ was isolated using rehydration and centrifugation method from a soil sample obtained from Rishiri Island in Japan. The taxonomic status of this organism was established using a polyphasic approach. Cells of strain RI50-RCA1 $14^{\top}$ were Gram positive, aerobic, motile and formed irregular sporangia. The strain grew in the presence of $0-2 \%(w / v) ~ N a C l$, between pH 5 and 8 , and over a temperature range of $20-37^{\circ} \mathrm{C}$, with optimal growth at $30^{\circ} \mathrm{C}$. Whole-cell hydrolysates of the strain contained meso-diaminopimelic acid, galactose, glucose and mannose, in addition to one unidentified O-methyl-hexose. The predominant menaquinone was $\mathrm{MK}-9\left(\mathrm{H}_{4}\right)$, and the major polar lipids comprised phosphatidylethanolamine, diphosphatidylglycerol and phosphatidyl- $N$-methylethylethanolamine. The major cellular fatty acids were iso- $\mathrm{C}_{16: 0}$, iso- $\mathrm{C}_{15: 0}$ and anteiso- $\mathrm{C}_{17: 0 .}$. Comparative 16S ribosomal RNA gene sequence analysis revealed that strain RI50-RCA114 ${ }^{\top}$ had the closest sequence similarity with Actinoplanes globisporus JCM $3186^{\top}(97.6 \%)$. However, DNA-DNA hybridization assays as well as physiological and biochemical analyses differentiated strain RI50-RCA $114^{\top}$ from its closest phylogenetic relative. On the basis of these data, we propose that strain RI50-RCA114 ${ }^{\top}$ (=NBRC $108556^{\top}=$ BCC $_{49184^{\top}}$ ) be classified as the type strain of a novel Actinoplanes species and named Actinoplanes rishiriensis sp. nov.

The Journal of Antibiotics (2012) 65, 249-253; doi:10.1038/ja.2012.8; published online 22 February 2012

Keywords: Actinoplanes; motile actinomycetes; polyphasic taxonomy

\section{INTRODUCTION}

The genus Actinoplanes ${ }^{1-3}$ that currently comprises 30 species is a member of the family Micromonosporaceae. ${ }^{4,5}$ All species in this genus are motile with respect to spores and the formation of spherical, subspherical, cylindrical or highly irregular sporangia. ${ }^{3,6}$ Several researchers have described selective isolation techniques for motile actinomycetes including those used in the genus Actinoplanes. ${ }^{6,7}$ For example, rehydration and centrifugation method is a highly selective method of isolation based on differential centrifugation and chemotactic properties. ${ }^{8}$ Recently, novel actinomycetes have been screened by using rehydration and centrifugation method, including A. tovensis, A. tereljensis and Luteipulveratus mongoliensis. ${ }^{9,10}$ The genus Actinoplanes produces several types of antibiotics including peptides/depsipeptides, polyene-type macrolides and aromatic compounds. ${ }^{6}$ Representative antibiotics originated from Actinoplanes species are teichomycins, purpuromycin, mycoplanecins and lipiarmycin. ${ }^{11-14}$ Glucose/xylose isomerase was isolated from species of Actinoplanes missouriensis. ${ }^{15,16}$ Thus, the discovery of additional species of this genus will contribute both to an understanding of their ecological roles and to the provision of bioresources for industrial applications.
While screening for motile actinomycetes from a cool temperate area, we discovered strain RI50-RCA1 $14^{\mathrm{T}}$ in a soil sample collected from Rishiri Island, Hokkaido, Japan. The aim of the present study was to determine the taxonomic position of strain RI50-RCA114 ${ }^{\mathrm{T}}$ using a polyphasic taxonomic approach, which included chemotaxonomic, morphological, physiological, molecular and genomic characterizations.

\section{RESULTS AND DISCUSSION}

The almost complete 16S ribosomal RNA (rRNA) gene sequence (1477 nucleotide) of strain RI50-RCA114 ${ }^{\mathrm{T}}$ was compared with sequences of known bacterial species on the EzTaxon server (http:// www.eztaxon.org/). ${ }^{17}$ Results showed that this strain has the highest sequence similarity of $97.6 \%$ to Actinoplanes globisporus JCM $3186^{\mathrm{T}}$, followed by Actinoplanes brasiliensis DSM $43805^{\mathrm{T}}(97.3 \%)$ and Actinoplanes deccanensis NBRC $13994^{\mathrm{T}}$ (96.6\%). The similarity of the $16 \mathrm{~S}$ rRNA gene sequence to members of the genus Actinoplanes ranged from $95.0 \%-97.6 \%$. The phylogenetic tree constructed with $16 \mathrm{~S}$ rRNA gene sequence data by neighbor-joining method showed that strain RI50-RCA $114^{\mathrm{T}}$ formed a monophyletic clade with A. globisporus, and

${ }^{1}$ Division of Applied Biological Sciences, Interdisciplinary Graduate School of Medicine and Engineering, University of Yamanashi, Kofu, Japan and ${ }^{2}$ NITE Biological Resource Center (NBRC), National Institute of Technology and Evaluation, Kazusakamatari, Kisarazu, Chiba, Japan

Correspondence: Dr H Yamamura, Division of Applied Biological Sciences, Interdisciplinary Graduate School of Medicine and Engineering, University of Yamanashi, Takeda-4, Kofu 400-8511, Japan.

E-mail: hyamamura@yamanashi.ac.jp

Received 30 June 2011; revised 13 January 2012; accepted 13 January 2012; published online 22 February 2012 
this was supported by the maximum parsimony and maximumlikelihood method (Figure 1). However, A. brasiliensis did not form a cluster with strain RI50-RCA1 $14^{\mathrm{T}}$ and A. globisporus in any of the three tree-making algorithms.

The whole-cell hydrolysate of strain RI50-RCA $114^{\mathrm{T}}$ contained meso-diaminopimelic acid, galactose, glucose, mannose and one unidentified $O$-methyl-hexose. ${ }^{18}$ The major menaquinone was MK-9 $\left(\mathrm{H}_{4}\right)$. The predominant polar lipids were phosphatidylethanolamine, diphosphatidylglycerol (phospholipid type PII) ${ }^{19}$ and phoshatidyl- $N$ methylethylethanolamine (Supplementary Figure S1). Table 1 summarizes the cellular fatty-acid profiles of strain RI50-RCA1 $14^{\mathrm{T}}$ and its two closest phylogenetic relatives. The major fatty acids $(>10 \%$ of the total) detected in strain RI50-RCA1 $14^{\mathrm{T}}$ were iso- $\mathrm{C}_{15: 0}(12.4 \%)$, iso- $\mathrm{C}_{16: 0}(35.6 \%)$ and anteiso- $\mathrm{C}_{17: 0}(11.9 \%)$, a profile quite similar to A. globisporus. ${ }^{9}$ In contrast, A. brasiliensis was differentiated from RI50-RCA1 $14^{\mathrm{T}}$ and A. globisporus based on the presence of anteiso$\mathrm{C}_{15: 0}$ in the fatty-acid profile. ${ }^{9}$ The DNA G+C content of strain RI50-RCA $114^{\mathrm{T}}$ was $71.2 \mathrm{~mol} \%$. On the basis of phylogenetic and chemotaxonomic findings, strain RI50-RCA114 ${ }^{\mathrm{T}}$ was identified as a member of the genus Actinoplanes. Strain RI50-RCA114 ${ }^{\mathrm{T}}$ belonging to the genus Actinoplanes was further characterized on the basis of comparisons with its phylogenetic relative, A. globisporus.

Strain RI50-RCA114 ${ }^{\mathrm{T}}$ formed light brown to pale reddish orange substrate mycelia without aerial mycelia (Figure 2). The diameter of irregular sporangia that were directly formed from substrate mycelia ranged from 3 to $5 \mu \mathrm{m}$. Strain RI50-RCA1 $14^{\mathrm{T}}$ grew in the $\mathrm{pH}$ range of $5-8$ and in the presence of $0-2 \% \mathrm{NaCl}(w / v)$, with optimal growth conditions being $\mathrm{pH} 7.0$ and $0 \% \mathrm{NaCl}(w / v)$. The temperature range for growth was $20-37^{\circ} \mathrm{C}$, with the optimum of $30^{\circ} \mathrm{C}$. Strain
RI50-RCA1 $14^{\mathrm{T}}$ was differentiated from A. globisporus by the catalase reaction, gelatin liquefaction, degradation of calcium malate and Tween 20, utilization of lactose and enzyme activity of naphthol-ASBI-phosphohydrolase, $\beta$-glucuronidase, $\alpha$-mannosidase, valine arylamidase and the range of $\mathrm{pH}$ of growth (Table 2).

The DNA-DNA hybridization values between strain RI50-RCA114 ${ }^{\mathrm{T}}$ and A. globisporus NBRC $13912^{\mathrm{T}}$ were $<48 \%$, which is $<70 \%$ cut-off point recommended for the assignment of bacterial strains to the same genomic species. ${ }^{20}$

On the basis of the phenotypic and genotypic characteristics, strain RI50-RCA1 $14^{\mathrm{T}}$ represents a novel species within the genus Actinoplanes, for which the name Actinoplanes rishiriensis sp. nov. is proposed.

\section{Description of Actinoplanes rishiriensis sp. nov.}

Actinoplanes rishiriensis (ri.shi.ri.en'sis N.L. masc. adj. rishiriensis; of, or pertaining to Rishiri Island, Hokkaido, Japan, where the organism was originally isolated).

Cells are aerobic and Gram positive. Aerial mycelia are absent and vegetative mycelia have branched hyphae. Irregular sporangia are formed directly from substrate mycelia. Sporangiospores are motile. The substrate mycelium is light brown to pale reddish-orange, and soluble pigment is not produced. Whole-cell hydrolysates contain meso-diaminopimelic acids, galactose, glucose, mannose and one unidentified $O$-methyl-hexose. The major fatty acids $(>10 \%$ of total) are iso- $\mathrm{C}_{15: 0}$, iso- $\mathrm{C}_{16: 0}$ and anteiso- $\mathrm{C}_{17: 0}$. The polar lipid profile consists of phosphatidylethanolamine, phosphatidyl- $N$ methylethylethanolamine and diphosphatidylglycerol. MK-9 $\left(\mathrm{H}_{4}\right)$ is the major menaquinone. The organism grows at $20-37^{\circ} \mathrm{C}$, but not at 15 and $45^{\circ} \mathrm{C}$, in the presence of $0-2 \% \mathrm{NaCl}(w / v)$, and at an initial $\mathrm{pH}$

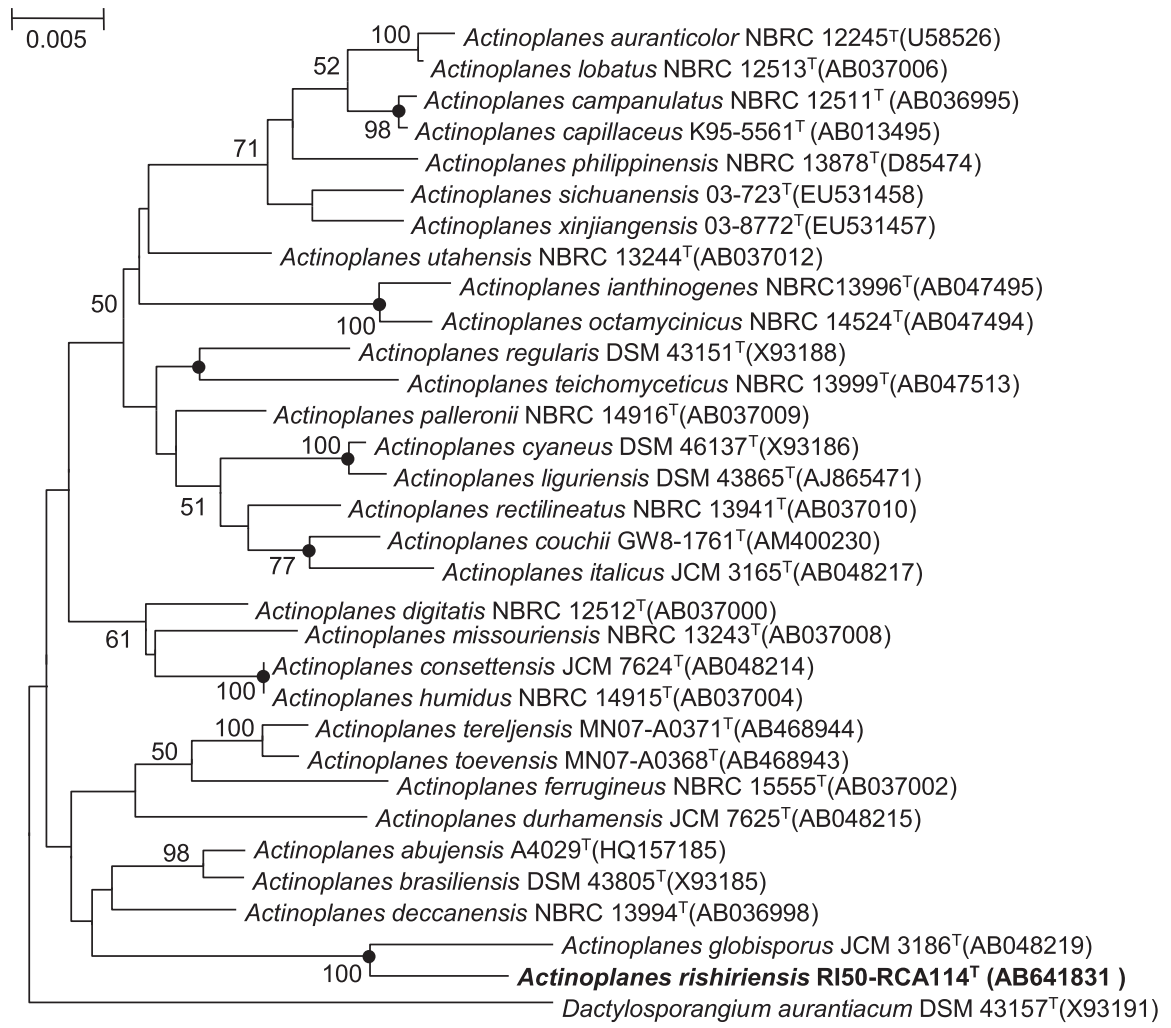

Figure 1 Phylogenetic tree derived from 16S rRNA gene sequences shows relationships between strain RI50-RCA114 and members of genus Actinoplanes. Root position of neighbour-joining tree was determined using Dactylosporangium aurantiacum DSM $43157^{\top}$ (X93191) as outgroup. The tree was constructed using neighbor-joining and $K_{\text {nuc }}$ values. ${ }^{39}$ Only bootstrap values $>50 \%$ are shown (1000 resamplings) at branching points. Solid circles indicate that corresponding nodes were also recovered in maximum parsimony and maximum-likelihood algorithms. ${ }^{40} \mathrm{Bar}, 0.005 K_{\text {nuc }}$. 
Table 1 Cellular fatty acid profiles of strain RI50-RCA114 ${ }^{\top}$ and its closest phylogenetic relatives

\begin{tabular}{|c|c|c|c|}
\hline Fatty acid & 1 & 2 & 3 \\
\hline \multicolumn{4}{|c|}{ Saturated straight-chain } \\
\hline $\mathrm{C}_{15: 0}$ & - & 1.0 & 3.0 \\
\hline $\mathrm{C}_{16: 0}$ & - & 3.6 & 1.7 \\
\hline$C_{17: 0}$ & 1.5 & 3.0 & 5.1 \\
\hline $\mathrm{C}_{18: 0}$ & - & 3.8 & 1.4 \\
\hline \multicolumn{4}{|l|}{ Saturated branched } \\
\hline iso- $\mathrm{C}_{14: 0}$ & 3.3 & - & 1.5 \\
\hline iso- $C_{15: 0}$ & 12.4 & 17.6 & 10.1 \\
\hline anteiso- $\mathrm{C}_{15: 0}$ & 4.3 & 3.4 & 24.5 \\
\hline iso- $\mathrm{C}_{16: 0}$ & 35.6 & 20.1 & 17.1 \\
\hline anteiso- $\mathrm{C}_{16: 0}$ & - & 1.4 & - \\
\hline $\mathrm{C}_{16: 0}$ 9-methyl & 3.7 & - & - \\
\hline iso- $\mathrm{C}_{16: 0} 2-\mathrm{OH}$ & 3.1 & 7.9 & - \\
\hline iso- $\mathrm{C}_{17: 0}$ & 5.5 & 9.7 & 2.1 \\
\hline anteiso- $\mathrm{C}_{17: 0}$ & 11.9 & 10.3 & 18.8 \\
\hline iso- $\mathrm{C}_{17: 0} 2-\mathrm{OH}$ & - & 1.7 & 2.2 \\
\hline anteiso- $\mathrm{C}_{17: 0} 2-\mathrm{OH}$ & - & 4.7 & - \\
\hline $\mathrm{C}_{17: 0}$ 10-methyl & 1.2 & - & - \\
\hline iso- $\mathrm{C}_{18: 0}$ & 1.3 & - & - \\
\hline \multicolumn{4}{|l|}{ Unsaturated } \\
\hline$C_{16: 1} \omega 9 c$ & 1.3 & - & - \\
\hline Anteiso- $\mathrm{C}_{17: 1}$ & 1.4 & - & - \\
\hline$C_{17: 1} \omega 9 c$ & 6.9 & 1.3 & 7.0 \\
\hline $\mathrm{C}_{18: 1} \omega 9 \mathrm{c}$ & 3.5 & 3.9 & 1.9 \\
\hline
\end{tabular}

Abbreviations: Strain 1, A. rishiriensis RI50-RCA114 ${ }^{\top}$; Strain 2, A. globisporus NBRC $13912^{\top}$ (data from Ara et al. ${ }^{11}$ ); Strain 3, A. brasiliensis NBRC $13938^{\top}$ (data from Ara et al. ${ }^{11}$ ). - , undetectable or detected in trace amounts. Bold entries indicate $>10 \%$ of the total fatty acids.

of $5-8$, with an optimum of $\mathrm{pH} 7$. Nitrate is reduced and the catalase reaction is negative. Tyrosine, casein, starch and Tween 20 are hydrolyzed, but not gelatin and calcium malate. Urease is weakly positive. L-arabinose, D-mannose, xylose, lactose, rhamnose and sucrose are utilized as sole carbon sources, but not sodium acetate, sorbitol, glycerol or D-ribose. The API ZYM, tests for alkaline phosphatase, naphthol-AS-BI-phosphohydrolase, $\beta$-glucuronidase, $\beta$-glucosidase and $N$-acetyl- $\beta$-glucosaminidase are positive. Tests for esterase (C4), esterase lipase (C8), $\beta$-galactosidase and $\alpha$-glucosidase are weakly positive. Activities of lipase (C14), leucine arylamidase, valine arylamidase, cystine arylamidase, trypsin, $\alpha$-chymotrypsin, acid phosphatase, $\alpha$-galactosidase, $\alpha$-mannosidase and $\alpha$-fucosidase are negative. The DNA G+C content of the type strain is $71.2 \mathrm{~mol} \%$.

The type strain is RI50-RCA1 $14^{\mathrm{T}}\left(=\mathrm{NBRC} 108556^{\mathrm{T}}=\mathrm{BCC} 49184^{\mathrm{T}}\right)$, isolated from a soil sample collected on Rishiri Island, Hokkaido, Japan.

\section{MATERIALS AND METHODS}

\section{Isolation and maintenance of organism}

A soil sample collected from Rishiri Island, Hokkaido, Japan was air-dried for 7 days at room temperature and passed through a 2-mm mesh sieve. Actinomycetes were then isolated as follows. The sample was processed using rehydration and centrifugation method as described by Hayakawa et al. ${ }^{8}$ spread on humic acid-vitamin agar $^{21}$ containing nalidixic acid $\left(20 \mathrm{mgl}^{-1}\right)$ and cycloheximide $\left(50 \mathrm{mgl}^{-1}\right.$ ), and then incubated at $30^{\circ} \mathrm{C}$ for 2 weeks. Thereafter, strain RI50-RCA1 $14^{\mathrm{T}}$ was isolated and transferred to oatmeal-yeast extract-glucoseglycerol (OYGG) agar ${ }^{22}$ and maintained in $20 \%(v / v)$ glycerol at $-80^{\circ} \mathrm{C}$.
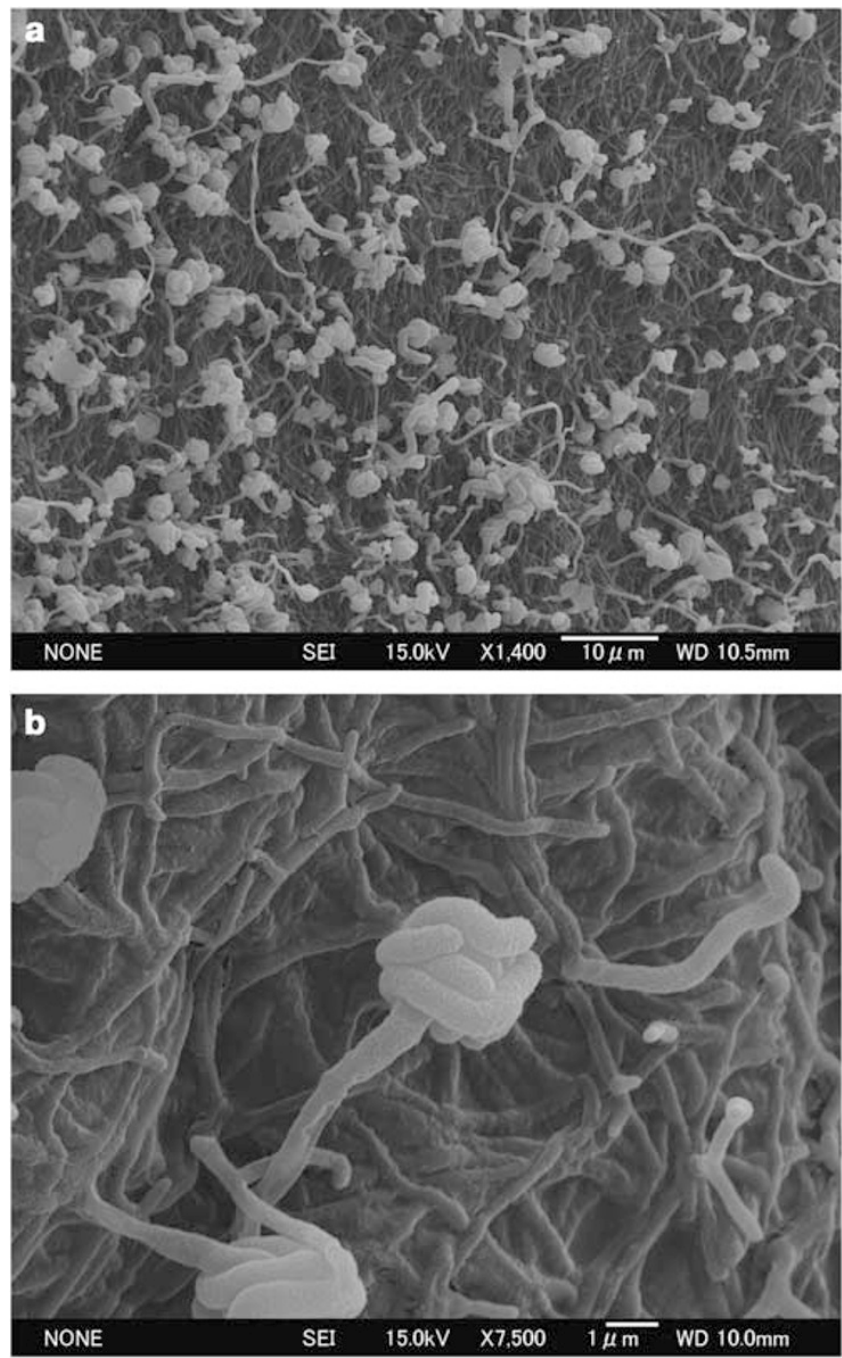

Figure 2 Scanning electron micrographs of strain RI50-RCA $114^{\top}$ cultured on $\mathrm{HA}$ for 2 weeks at $30^{\circ} \mathrm{C}$. Bar indicates 10 (a) or 1 (b) $\mu \mathrm{m}$.

\section{Phenotypic characterization}

Strain RI50-RCA1 $14^{\mathrm{T}}$ grew on HA agar for 14 days at $28^{\circ} \mathrm{C}$, and morphological features were analyzed using light and scanning electron microscopy (JEOL, Tokyo, Japan, JSM-6500F). ${ }^{23}$ We used light microscopy to evaluate motility in spores suspended in hanging drops of phosphate buffer-soil extract solution. ${ }^{8}$ Spores were Gram-stained according to Hucker. ${ }^{24}$ To determine the optimal temperature and $\mathrm{pH}$ for growth, strain RI50-RCA114 ${ }^{\mathrm{T}}$ was incubated for 7 and 14 days on oatmeal-YGG agar at temperatures of $5,10,20,30,37,40$ and $45^{\circ} \mathrm{C}$, and at $\mathrm{pH}$ values ranging from 5 to 11 (in $1 \mathrm{pH}$ unit intervals). Growth at 5 and $10{ }^{\circ} \mathrm{C}$ was assayed after 6 weeks of incubation. Growth in various concentrations of $\mathrm{NaCl}(0-8 \%, w / v$, in $1 \%$ increments) was evaluated after 14 and 21 days of incubation on Bennett's agar. ${ }^{25}$ Several physiological and biochemical characteristics were evaluated using API ZYM Biochemical Test Kits (bioMérieux, Tokyo, Japan) according to the manufacturer's instructions. Assimilation of carbon sources at a final concentration of $1 \%(w / v)$ was tested using International Streptomyces Project (ISP) medium 9 as the basal medium. ${ }^{26}$

\section{Chemotaxonomy}

Biomass was generated for chemotaxonomic studies by shaking strain RI50RCA $114^{\mathrm{T}}$ in glucose-yeast extract broth for $5-7$ days at $30^{\circ} \mathrm{C} .{ }^{27}$ Pelleted cells harvested by centrifugation were washed twice with distilled water. Diaminopimelic acid isomers and sugars in whole-cell hydrolysates were then analyzed 
Table 2 Differential characteristics of strain RI50-RCA114 ${ }^{\top}$ and its closest phylogenetic relative

\begin{tabular}{lcc}
\hline Characteristic & 1 & 2 \\
\hline $\mathrm{NaCl}$ tolerance (\%) & $0-2$ & $0-3$ \\
Growth $\mathrm{pH}$ & $5-8$ & $5-11$ \\
Catalase reaction & - & + \\
Gelatin liquefaction & - & +
\end{tabular}

Degradation of

Calcium malate

Tween 20

Utilization of

Lactose

Enzyme activity of

Naphthol-AS-BI-phosphohydrolase

$\beta$-Glucuronidase

$\alpha$-Mannosidase

$+$

Abbreviations: Strain 1, A. rishiriensis RI50-RCA114'; Strain 2, A. globisporus NBRC $13912^{\top}$. + , positive; -, negative.

All data were generated in the present study.

based on the methods described by Hasegawa et al. ${ }^{28}$ and Tamura et al., ${ }^{18}$ respectively. Cellular fatty acids were processed and analyzed as methyl esters, following the protocol of the MIDI Sherlock Microbial Identification System. ${ }^{29}$ Isoprenoid quinones and polar lipids were extracted and isolated using standard procedures, ${ }^{30}$ and the results were compared with those of appropriate controls. The isoprenoid quinone content was determined using liquid chromatography/mass spectrometry described by Hamada et al. ${ }^{31}$ The polar lipids were identified by two dimensional thin-layered chromatography, followed by spraying with appropriate detection reagents according to the method of Yassin et al. ${ }^{32}$ The DNA G+C content of strain RI50-RCA114 ${ }^{\mathrm{T}}$ was determined by HPLC as described by Tamaoka and Komagata ${ }^{33}$

\section{Molecular analysis}

Chromosomal DNA from strain RI50-RCA114 ${ }^{\mathrm{T}}$ was isolated and purified as described by Saito and Miura ${ }^{34}$ with a minor modification. ${ }^{35}$ The 16S rRNA gene from strain RI50-RCA114 ${ }^{\mathrm{T}}$ was amplified by PCR as described by Tamura and Hatano ${ }^{36}$ and the PCR product was purified using MonoFas DNA Purification Kits (GL Sciences, Tokyo, Japan). The purified PCR product was directly sequenced using ABI Prism BigDye Terminator Cycle Sequencing Kits (Applied Biosystems, Foster City, CA, USA) and a Genetic Analyzer automated DNA sequencer (model 3730; Applied Biosystems). The 16S rRNA gene sequence was compared with published 16S rRNA gene sequences of bacterial type strains using the EzTaxon server. ${ }^{17}$ For phylogenetic analyses, $16 \mathrm{~S}$ rRNA gene sequences were collected from the EMBL/GenBank/DNA Data Bank of Japan database and aligned using the CLUSTAL_X program. ${ }^{37}$ Phylogenetic trees were constructed using the CLUSTAL_X program $^{37}$ and Molecular Evolutionary Genetics Analysis (MEGA) software version $5.0^{38}$ with neighborjoining, maximum parsimony and maximum-likelihood methods. ${ }^{39,40}$ The topologies of the constructed trees were evaluated by bootstrap analysis with either 1000 (neighbor-joining and maximum-parsimony methods) or 500 resamplings (maximum-likelihood method). ${ }^{41}$

\section{DNA-DNA hybridization}

DNA-DNA hybridization proceeded as described by Kusunoki et al. ${ }^{42}$ using biotinylated DNA, with five replications for each sample. The highest and lowest values obtained for each sample were excluded, and the mean of the remaining three values is quoted as the DNA-DNA relatedness value.
Nucleotide sequence accession number

The $16 \mathrm{~S}$ rRNA gene sequence of strain RI50-RCA1 $14^{\mathrm{T}}$ determined in this study has been deposited in the DNA Data Bank of Japan database under the accession number AB641831.

\section{ACKNOWLEDGEMENTS}

This study was supported in part by a research grant from the Institute for Fermentation, Osaka (IFO), Japan. We are grateful to Dr Jean P Euzéby for support with nomenclature.

1 Goodfellow, M., Stanton, L. J., Simpson, K. E. \& Minnikin, D. E. Numerical and chemical classification of Actinoplanes and some related actinomycetes. J. Gen. Microbiol. 136, 19-36 (1990).

2 Couch, J. N. Actinoplanes, a new genus of the Actinomycetales. J. Elisha Mitchell Sci. Soc. 66, 87-92 (1950)

3 Stackebrandt, E. \& Kroppenstedt, R. M. Union of the genera Actinoplanes Couch, Ampullariella Couch, and Amorphosporangium Couch in a redefined genus Actinoplanes. Syst. Appl. Microbiol. 9, 110-114 (1987).

4 Krassil'nikov, N. A. Ray fungi and related organisms, Actinomycetales (Izdatel'stvo Akademii Nauk SSSR, Moscow, 1938).

5 Zhi, X. Y., Li, W. J. \& Stackebrandt, E. An update of the structure and 16S rRNA gene sequence-based definition of higher ranks of the class Actinobacteria, with the proposal of two new suborders and four new families and emended descriptions of the existing higher taxa. Int. J. Syst. Evol. Microbiol. 59, 589-608 (2009).

6 Vobis, G. The genus Actinoplanes and related genera in The Prokaryotes: a Handbook on the Biology of Bacteria 3rd edn, Vol. 3 (eds Dworkin, M. Falkow, S. Rosenberg, E. Schleifer, K. H. \& Stackebrandt, E.) 623-653 (Springer, New York, 2006).

7 Hayakawa, M. Studies on the isolation and distribution of rare actinomycetes in soil. Actinomycetologica 22, 12-19 (2008).

8 Hayakawa, M., Otoguro, M., Takeuchi, T., Yamazaki, T. \& limura, Y. Application of a method incorporating differential centrifugation for selective isolation of motile actinomycetes in soil and plant litter. Antonie Van Leeuwenhoek 78, 171-185 (2000).

9 Ara, I., Yamamura, H., Tsetseg, B., Daram, D. \& Ando, K. Actinoplanes toevensis sp. nov. and Actinoplanes tereljensis sp. nov., isolated from Mongolian soil. Int. J. Syst. Evol. Microbiol. 60, 919-927 (2010).

10 Ara, I., Yamamura, H., Tsetseg, B., Daram, D. \& Ando, K. Luteipulveratus mongoliensis gen. nov., sp. nov., an actinobacterial taxon in the family Dermacoccaceae. Int. J. Syst. Evol. Microbiol. 60, 574-579 (2010).

11 Parenti, F., Beretta, G., Berti, M. \& Arioli, V. Teichomycins, new antibiotics from Actinoplanes teichomyceticus nov. sp. I. Description of the producer strain, fermentation studies and biological properties. J. Antibiot. 31, 276-283 (1978).

12 Coronelli, C., Pagani, H., Bardone, M. R. \& Lancini, G. C. Purpuromycin, a new antibiotic isolated from Actinoplanes ianthinogenes nov. sp. J. Antibiot. 27, 161-168 (1974).

13 Torikata, A. et al. Mycoplanecins, novel antimycobacterial antibiotics from Actinoplanes awajinensis subsp. mycoplanecinus subsp. nov. I. Taxonomy of producing organism and fermentation. J. Antibiot. 36, 957-960 (1983).

14 Parenti, F., Pagani, H. \& Beretta, G. Lipiarmycin, a new antibiotic from Actinoplanes. I. Description of the producer strain and fermentation studies. J. Antibiot. 28, 247-252 (1975).

15 Amore, R. \& Hollenberg, C. P. Xylose isomerase from Actinoplanes missouriensis: primary structure of the gene and protein. Nucleic Acids Res. 17, 7515 (1989).

16 Gong, C. S., Chen, L. F. \& George, T. Purification and properties of glucose isomerase of Actinoplanes missouriensis. Biotechnol. Bioeng. 22, 833-845 (1980).

17 Chun, J. et al. EzTaxon: a web-based tool for the identification of prokaryotes based on 16S ribosomal RNA gene sequences. Int. J. Syst. Evol. Microbiol. 57, 2259-2261 (2007).

18 Tamura, T., Ishida, Y. \& Suzuki, K.-I. Descriptions of Actinoplanes ianthinogenes nom. rev. and Actinoplanes octamycinicus corrig. comb. nov., nom. rev. Int. J. Syst. Evol. Microbiol. 61, 2916-2921 (2011).

19 Lechevalier, M. P., De Bivre, C. \& Lechevalier, H. A. Chemotaxonomy of aerobic actinomycetes: phospholipid composition. Biochem. Syst. Ecol. 5, 249-260 (1977).

20 Wayne, L. G. et al. Report of the ad hoc committee on reconciliation of approaches to bacterial systematics. Int. J. Syst. Bacteriol. 37, 463-464 (1987).

21 Hayakawa, M. \& Nonomura, H. Humic acid-vitamin agar, a new medium for the selective isolation of soil actinomycetes. J. Ferment. Technol. 65, 501-509 (1987).

22 Hayakawa, M., lino, S. \& Nonomura, H. Heavy metal resistance and melanoid pigment production in the streptomycete flora of copper-polluted vineyard soils. J. Ferment. Technol. 60, 1-9 (1982).

23 Nonomura, H., lino, S. \& Hayakawa, M. Classification of actinomycete genus Ampullariella from soils of Japan. J. Ferment. Technol. 57, 79-85 (1979).

24 Gerhardt, P. Manual of Methods for General Bacteriology (American Society for Microbiology, Washington, DC, 1981).

25 Jones, K. L. Fresh isolates of actinomycetes in which the presence of sporogenous aerial mycelia is a fluctuating characteristic. J. Bacteriol. 57, 141-145 (1949).

26 Shirling, E. B. \& Gottlieb, D. Methods for characterization of Streptomyces species. Int. J. Syst. Bacteriol. 16, 313-340 (1966). 
27 Gordon, R. E. \& Mihm, J. M. Identification of Nocardia caviae (Erikson) nov. comb. Ann. NY. Acad. Sci. 98, 628-636 (1962).

28 Hasegawa, T., Takizawa, M. \& Tanida, S. A rapid analysis for chemical grouping of aerobic actinomycetes. J. Gen. Appl. Microbiol. 29, 319-322 (1983).

29 Sasser, M. Identification of Bacteria by Gas Chromatography of Cellular Fatty Acids. (Microbial ID Inc., Newark, DE, 1990).

30 Minnikin, D. E. et al. An integrated procedure for the extraction of bacterial isoprenoid quinines and polar lipids. J. Microbiol. Methods 2, 233-241 (1984).

31 Hamada, M. et al. Mobilicoccus pelagius gen. nov., sp. nov. and Piscicoccus intestinalis gen. nov., sp. nov., two new members of the family Dermatophilaceae, and reclassification of Dermatophilus chelonae (Masters et al. 1995) as Austwickia chelonae gen. nov., comb. nov. J. Gen. Appl. Microbiol. 56, 427-436 (2010).

32 Yassin, A. F., Haggenei, B., Budzikiewicz, H. \& Schaal, K. P. Fatty acid and polar lipid composition of the genus Amycolatopsis: application of fast atom bombardment-mass spectrometry to structure analysis of underivatized phospholipids. Int. J. Syst. Bacteriol. 43, 414-420 (1993).

33 Tamaoka, J. \& Komagata, K. Determination of DNA base composition by reversed-phase high-performance liquid chromatography. FEMS Microbiol. Lett. 25, 125-128 (1984).

34 Saito, H. \& Miura, K.-I. Preparation of transforming deoxyribonucleic acid by phenol treatment. Biochim. Biophys. Acta. 72, 619-629 (1963).

35 Hatano, K., Nishii, T. \& Kasai, H. Taxonomic re-evaluation of whorl-forming Streptomyces (formerly Streptoverticillium) species by using phenotypes, DNA-DNA hybridization and sequences of gyrB, and proposal of Streptomyces luteireticuli (ex Katoh and
Arai 1957) corrig., sp. nov., nom. rev. Int. J. Syst. Evol. Microbiol. 53, 1519-1529 (2003).

36 Tamura, T. \& Hatano, K. Phylogenetic analysis of the genus Actinoplanes and transfer of Actinoplanes minutisporangius Ruan et al. 1986 and 'Actinoplanes aurantiacus' to Cryptosporangium minutisporangium comb. nov. and Cryptosporangium aurantiacum sp. nov. Int. J. Syst. Evol. Microbiol. 51, 2119-2125 (2001).

37 Thompson, J. D., Gibson, T. J., Plewniak, F., Jeanmougin, F. \& Higgins, D. G. The CLUSTAL_X Windows interface: flexible strategies for multiple sequence alignment aided by quality analysis tools. Nucleic Acids Res. 25, 4876-4882 (1997).

38 Tamura, K. et al. MEGA5: Molecular evolutionary genetics analysis using maximum likelihood, evolutionary distance, and maximum parsimony methods. Mol. Biol. Evol. 28, 2731-2739 (2011).

39 Saitou, N. \& Nei, M. The neighbor-joining method: a new method for reconstructing phylogenetic trees. Mol. Biol. Evol. 4, 406-425 (1987).

40 Takahashi, K. \& Nei, M. Efficiencies of fast algorithms of phylogenetic inference under the criteria of maximum parsimony, minimum evolution, and maximum likelihood when a large number of sequences are used. Mol. Biol. Evol. 17, 1251-1258 (2000).

41 Felsenstein, J. Confidence limits on phylogenies: an approach using the bootstrap. Evolution 39, 783-791 (1985)

42 Kusunoki, S. et al. Application of calorimetric microdilution plate hybridization for rapid generic identification of 22 Mycobacterium species. J. Clin. Microbiol. 29, 1596-1603 (1991).

Supplementary Information accompanies the paper on The Journal of Antibiotics website (http://www.nature.com/ja) 